\title{
A comparison of soil respiration, carbon balance and root carbon use efficiency in two managed Moso bamboo forests in subtropical China
}

\author{
X. Tang, S. Fan, L. Qi, F. Guan, W. Su, M. Du
}

Tang X., Fan S., Qi L., Guan F., Su W., Du M., 2016. A comparison of soil respiration, carbon balance and root carbon use efficiency in two managed Moso bamboo forests in subtropical China. Ann. For. Res. 59(1): 3-20.

Abstract. Moso bamboo forest (Phyllostachys heterocycla [Carr.] Mitford cv. Pubescens) is an important forest type in subtropical China and comprises an important pool in the global carbon cycle. Understanding the effects of the stand management, such as understory removal, on soil respiration (RS) will help to provide a more accurate estimation of carbon cycling and predict future climate change. The study aimed to compare RS and net ecosystem production (NEP) in two Moso bamboo forests managed by the application of herbicide $(\mathrm{AH})$ and conventional hand-weeded (HW) treatment, and further examine their root carbon use efficiency (RCUE). Trenching and litter removal were used to partition the source components of RS and one-year field measurement was conducted. Maximum-minimum approach was used to estimate fine root production. NEP was determined by the balance between NPP of vegetation and heterotrophic respiration $(\mathrm{RH})$ of soil. RCUE was calculated using an indirect method. In both stands, soil temperature and soil moisture at $5 \mathrm{~cm}$ depth were the main driving forces to the seasonality of RS. Annual RS was $31.6 \mathrm{t} \mathrm{CO}_{2} \mathrm{ha}^{-1}$ for the stand $\mathrm{AH}$ and $33.9 \mathrm{t} \mathrm{CO}_{2} \mathrm{ha}^{-1}$ for the stand $\mathrm{HW}$, while net ecosystem production (NEP) were 21.9 and $21.1 \mathrm{t} \mathrm{CO}_{2} \mathrm{ha}^{-1}$, respectively, indicating that the both Moso bamboo stands acted as carbon sinks in the scenarios of current climate change. The RCUE was $30.6 \%$ for the stand AH, which was significantly lower than that for the stand HW (58.8\%). This result indicates that different stand management practices can alter RCUE and the assumed constant universal carbon use efficiency (CUE) of 50\% is not appropriate in Moso bamboo forests. This study highlight the importance of partition the source components of RS and accurate estimation of RCUE in modelling carbon cycling in Moso bamboo forests.

Keywords soil respiration, carbon cycling, net ecosystem production, carbon use efficiency, Moso bamboo forests

Authors. Xiaolu Tang - Key Laboratory of Bamboo and Rattan Science, International Centre for Bamboo and Rattan, Wangjing, Chaoyang District, Beijing 100102, China; Department of Forest Inventory and Remote Sensing, Burckhardt Institute, Georg-August-Universität Göttingen, 37077 Göttingen, Germany; Shaohui Fan (fansh@icbr.ac.cn), Lianghua Qi, Fengying Guan (guanfy@ icbr.ac.cn), Wenhui Su - Key Laboratory of Bamboo and Rattan Science, International Centre for Bamboo and Rattan, Wangjing, Chaoyang District, Beijing 
100102, China; Manyi Du - Experimental Center of Forestry in North China, Chinese Academy of Forestry, Beijing 102300, China.

Manuscript received August 14, 2015; revised December 21, 2015; accepted January 15, 2016; online first January 28, 2016.

\section{Introduction}

Soil respiration (RS), a primary $\mathrm{CO}_{2}$ exchange process between soil and atmosphere, is the second largest carbon (C) flux in global C cycling after gross primary productivity (Raich \& Schlesinger 1992). Approximately 83\% of the gross primary productivity of terrestrial ecosystems return back to atmosphere due to ecosystem respiration, and $30 \%$ to $80 \%$ comes from RS (Davidson \& Janssens 2006, Davidson et al. 2000, Law et al. 2002). C release from $\mathrm{RS}$ is estimated to be $98 \mathrm{Pg} \mathrm{C}$ per year in 2008 ( $1 \mathrm{Pg} \mathrm{C}=10^{15} \mathrm{~g} \mathrm{C}$ ) (Bond-Lamberty $\&$ Thomson 2010). This amount is more than 10 times of that from fossil fuel combustion (IPCC 2007). Therefore, a minor change in RS could significantly affect the atmospheric $\mathrm{CO}_{2}$ concentrations and an understanding of the belowground $\mathrm{C}$ process is becoming increasingly important to estimate global $\mathrm{C}$ budget (Wu et al. 2014b).

RS consists of rhizoshperic respiration (respiration from roots, mycorrhizae and microbial respiration in the rhizosphere) and heterotrophic respiration (respiration by microbial organisms and soil fauna) (Bond-Lamberty et al. 2004, Wang \& Yang 2007). Soil temperature, moisture and substrate quality are important environmental factors driving the changes of RS (Subke \& Bahn 2010, Wang et al. 2010).

However, the rhizoshperic respiration and heterotrophic respiration responded differently to environmental conditions (Giardina \& Ryan 2000, Högberg et al. 2001), and are driven by different mechanisms (Wang \& Yang 2007). For example, photosynthesis and fine root biomass have been recognized as important drivers of rhizospheric respiration (Kuzyakov
\& Gavrichkova 2010). Therefore, partitioning $\mathrm{RS}$ is an essential step to understand global carbon cycling (Hanson et al. 2000, Wang \& Yang 2007).

Carbon use efficiency (CUE), defined as the ratio of net primary production and gross primary production (Chambers et al. 2004), can be applied to assess not only the capacity of forests to transfer $\mathrm{C}$ from the atmosphere to the terrestrial biomass, but also to determine the impact of respiration on productivity in forests (Chambers et al. 2004, Manzoni et al. 2012). CUE is a very helpful ecological parameter to determine whether the terrestrial ecosystem is a C source or sink (Zhu 2013). In many landscape-scale carbon cycling models, the constant CUE is widely assumed (DeLucia et al. 2007). However, the constant value is doubtful to the universal uses (Ryan et al. 1997, Tan et al. 2010, Zhu 2013). For example, the CUE is $34 \%$ in a primary tropical seasonal rain forest (Tan et al. 2010) and 27\% for a young jack pine forest (Ryan et al. 1997).

Moreover, CUE also differs in aboveground, belowground and organs (Zhu 2013). Generally, CUE of aboveground is higher than that of belowground (Zhu 2013), and stem wood CUE is higher than leaf and root CUE (RCUE) (Chambers et al. 2004, Tan et al. 2010). As one of the most important part in forest ecosystem, RCUE is less intensively studies due to the direct measurement of CUE and labour intensity. Based on a meta-analysis of worldwide mature forests, Chen et al. (2011) found RCUE ranges from 0.10 to 0.87 . However, to our knowledge, a study on RCUE in bamboo forests has not been observed.

As a special forest type in Southern China, bamboo forest is well-known for fast biomass accumulation ( $\mathrm{Du}$ et al. 2010). The area of 
bamboo forests has increased from 3.05 million hectares in 1973 to 6.2 million hectares in 2013, 70\% of which is Moso bamboo forest (Phyllostachys heterocycla [Carr.] Mitford cv. Pubescens) (State Forestry Adiministration 2014). The $\mathrm{C}$ stock in bamboo forests contributes $11 \%$ of the total $\mathrm{C}$ stock of China's forest ecosystems (Chen et al. 2009). Therefore, bamboo forests play a critical role in regional, national, even in global $\mathrm{C}$ cycle (Tu et al. 2013). In recent decades, Moso bamboo has expanded fast driven by good price and sustainable forest development policies (Wang et al. 2008). To have good timber output, regular management, such as understory removal, tillage and fertilization has been widely applied (Liu et al. 2011). Effects of understory removal on RS in Chinese chestnut plantations (Zhang et al. 2013), Eucalyptus plantations (Wu et al. 2011), and mixed Magnoliaceae glanca, Liquidambar formosana and Tsoongiodendron odorum plantations (Wang et al. 2011b) have been observed. It is expected that understory removal affects RS and RCUE due to the changes in soil environment and root biomass (Wang et al. 2011b). However, RS and RCUE in Moso bamboo forests managed under understory removal treatment have been not observed. Therefore, this study aimed to: (1) describe the seasonality of RS and compared the effects of two understory removal practices on RS dynamics; (2) qualify the relationships between RS and its source components and soil temperature and moisture; (3) estimate annual RS and ecosystem carbon balance; (4) compare the effects of two understory removal practices on RCUE and test whether the constant RCUE value of $50 \%$ is available to Moso bamboo forests.

\section{Materials and methods}

\section{Study area}

The study area is located in a Forest Farm in
Xianning city $\left(29^{\circ} 02^{\prime}\right.$ to $30^{\circ} 19^{\prime} \mathrm{N}, 113^{\circ} 32^{\prime}$ to $\left.114^{\circ} 58^{\prime}, \mathrm{E}\right)$, Hubei province, China. It has a typical subtropical monsoon climate with a forest cover of $52.3 \%$. The annual precipitation is $1496.2 \mathrm{~mm}$ with $72 \%$ occurring in spring and summer (Liu et al. 2012). The mean annual temperature is $17.1^{\circ} \mathrm{C}$ (Liu et al. 2012). The lowest temperature was $-15.4{ }^{\circ} \mathrm{C}$ in January while the highest temperature was 41.4 ${ }^{\circ} \mathrm{C}$ in July. There are 245 258 frost-free days annually.

The pure Moso bamboo forests were established since the 1960 s, currently these expanded to an area of about 400 hectares. Many understory, including Castanopsis tessellate, Castanea seguinii, Castanopsis tibetana, Rhus chinensis, Lirildendron chinense, Loropetalum Chinense, Smilax glabra and some grasses, were found under the canopy. To improve bamboo production and reduce the competitions between bamboo and understory, understory removals are widely used.

\section{Experimental design}

Two Moso bamboo stands with similar site conditions (soil, stand structure) managed by the application of herbicides $(\mathrm{AH})$ and conventional hand-weeded (HW), which were the typical management practices of local area, were selected. The application of herbicides, consisting a solution of Nonda and Jialijia with $5 \%$ concentration, was conducted in every July in sunny days since 2000. Traditional hand-weeded was conducted twice a year in every May and September using billhook since 2000. In order to compare the two managements, the traditional hand-weeded was considered as a control. Therefore, the differences of RS between the two stands were considered as a result of different managements. However, it is recognized that such pseudo-replication is the limitation of such studies in forests. In March 2011, three $20 \mathrm{~m} \times 20 \mathrm{~m}$ plots were established for each stand. There was a $10 \mathrm{~m}$ buffer zone between the two adjacent plots. 
In each plot, four polyvinyl chloride collars (PVC, $20 \mathrm{~cm}$ inside diameter, $12 \mathrm{~cm}$ in height) were inserted into the intact soil $5 \mathrm{~m}$ away from the plot centre along a diagonal transect at a depth of $3 \mathrm{~cm}$ (Li et al. 2010b). The soil $\mathrm{CO}_{2}$ flux in the intact soil was the total RS. Similarly, soil $\mathrm{CO}_{2}$ flux with no litter (RNL) was measured on another four PVC collars installed on the litter-free soil, which were $50 \mathrm{~cm}$ away from PVC collars on the intact soil. The difference of soil $\mathrm{CO}_{2}$ flux between the intact and litter-free soil was litter respiration (RL).

To partition RR, an $80 \mathrm{~cm} \times 80 \mathrm{~cm}$ subplot was trenched to a depth of $80 \mathrm{~cm}$ in the plot centre in March 2011. Vegetation and litter in the subplots were removed carefully to minimize soil disturbance, and the subplots were kept free of live vegetation and litter throughout the study period. Since most of the bamboo roots were distributed within $40 \mathrm{~cm}$ of the surface (Tang et al. 2012), trenching to 80 $\mathrm{cm}$ was sufficient to achieve the objectives of this research. Four $0.5 \mathrm{~cm}$ thick polyethylene boards were inserted into the trenches vertically to prevent root ingrowth after trenching. Subsequently, two PVC collars were installed.

All PVC collars remained unchanged during the whole study period. The soil $\mathrm{CO}_{2}$ flux from these trenched subplots was the sum of the soil organic matter derived $\mathrm{CO}_{2}(\mathrm{RM})$ and root decomposition $\left(R_{\text {trench }}\right)$ because the dead roots were decomposed by soil microbes and animals and turned into humus. Therefore, dead root decomposition rate should be excluded.

Root decomposition rate $(v)$ was calculated (Lee et al. 2003):

$$
v=0.64 k
$$

where $v$ is the decomposition rate of dead roots $\left(\mu \mathrm{mol} \mathrm{CO} \mathrm{C}^{-2} \mathrm{~s}^{-1}\right), k$ is the relative decomposition rate constant obtained by the exponential decay function. $k$ is 0.6063 for fine root $(<2$ $\mathrm{mm})$ and 0.52 for coarse root $(>2 \mathrm{~mm})$ for bamboo forests (Fan et al. 2009b, Silver \& Miya 2001).
The $\mathrm{CO}_{2}$ flux due to the decomposition of residual roots of each size class $R_{d}(\mu \mathrm{mol} \mathrm{CO}$ $\mathrm{m}^{-2} \mathrm{~s}^{-1}$ ) at given time was calculated as follows:

$$
\begin{aligned}
& R_{d}=B_{r} \cdot\left(a \cdot e^{-v \cdot(t-1)}-a \cdot e^{-v \cdot t}\right) \\
& R_{D}=\sum R_{d}
\end{aligned}
$$

where $B_{r}$ is the root biomass for each size class $\left(\mathrm{g} \mathrm{m}^{-2}\right), t$ is the decomposition time $\left(\mathrm{a}^{-1}\right) . R_{D}$ is the total root decomposition rate $(\mu \mathrm{mol} \mathrm{CO}$ $\left.\mathrm{m}^{-2} \mathrm{~s}^{-1}\right) ; a$ is the intercept for dead root decomposition rate, which is 104.01 for bamboo forests (Fan et al. 2009b). The root sampling was described in details in the following section. Hence, RM and RR can be calculated:

$$
\begin{aligned}
& R M=R_{\text {trench }}-R_{D} \\
& R R=R N L-R M=R N L-\left(R_{\text {trench }}-R_{D}\right)
\end{aligned}
$$

\section{Root sampling and root NPP calculation}

Roots within $0-40 \mathrm{~cm}$ were collected by sequential soil cores ( $8 \mathrm{~cm}$ in diameter) in the middle of each month from April 2011 to March 2012, because most of the bamboo roots were distributed above $40 \mathrm{~cm}$ due to its special biological characteristics (Tang et al. 2012). Five soil cores were randomly selected in each plot. Roots with diameter $<2 \mathrm{~mm}$ were treated as fine roots, while roots with diameter $>2 \mathrm{~mm}$ were treated as coarse roots (Fan et al. 2009b, Tang et al. 2012). A total of 720 soil sequential cores were collected. The roots were washed free of soil manually in the flowing water. In the lab, root samples were dried to constant weight at $65{ }^{\circ} \mathrm{C}$ and weighted to $0.01 \mathrm{~g}$. The carbon concentration of root were determined by determined using the $\mathrm{K}_{2} \mathrm{Cr}_{2} \mathrm{O}_{7}-\mathrm{H}_{2} \mathrm{SO}_{4}$ wet oxidation method (Zhang et al. 1999). The fine root NPP was estimate by maximum-minimum approach (Brunner et al. 2013, McClaugherty et al. 1982): 


$$
N P P_{f r}=B_{\text {max }}-B_{\text {min }}
$$

where $N P P_{f r}$ is the fine root net primary production $\left(\mathrm{g} \mathrm{m}^{-2}\right), B_{\max }$ and $B_{\text {min }}$ are the maximum and minimum fine root biomass $\left(\mathrm{g} \mathrm{m}^{-2}\right)$.

Because $95 \%$ of biomass increment results from 1 "du" bamboos in Moso bamboo forests (Tang et al. 2015), and no diameter and height increment in 2, 3 and 4 "du" bamboos (Fu 2000), the coarse root production of 2, 3 and 4 "du" bamboo was ignored. Therefore, coarse root production of 1 "du" bamboos was estimated as the difference between new established belowground biomass and fine root NPP. The new established belowground biomass was estimated using the ratio of root/shoot of 0.2 (China Green Foundation 2008). Therefore, bamboo NPP was the sum of aboveground and belowground NPP.

\section{RS, soil temperature (ST) and soil moisture (SM) measurements}

One-year field measurement of RS was conducted using a Li-Cor-8100 (Li-Cor Inc., Lincoln, NE., USA) automated soil $\mathrm{CO}_{2}$ flux system starting from April 2011. Wang et al. (2011a) proposed that RS rates between 9:00 a.m. and 12:00 a.m. represent the diurnal average in Moso bamboo forests, therefore, we measured RS during that time period. ST and $\mathrm{SM}$ near the collars at a depth of $5 \mathrm{~cm}$ were measured using the ST and SM sensors of the Li-Cor-8100 while measuring $\mathrm{CO}_{2}$ flux over the entire study period.

\section{Carbon stock in vegetation layer}

In May 2011, the diameter at breast height (DBH, $1.3 \mathrm{~m}$ ) of all bamboos in the inventory plots were measured nearest to $0.1 \mathrm{~cm}$ with a diameter tape. At the same time, the age of each bamboo were recorded based on upon visual examination on the culm colour, eye- lash on cycle of culm sheath, powder under cycle of culm sheath and sheath in culm base (Zhang et al. 2014). The age was expressed by "du", which shows the growth habit in "onyear" and "off-year" bamboo stands. One "du" corresponds to 1-2 years, whereas 2-4 "du" represent 3-4, 5-6 and 7-8 years, respectively (Fu 2000). The aboveground biomass of individual bamboo stems was estimated using equation (1) (Zhou et al. 2010). For simplicity, 0.5 was used as carbon concentration to convert biomass to carbon (Zhou \& Jiang 2004).

where $A G B$ is the aboveground biomass; $A$ is the age (du) (Fu 2000, Zhou et al. 2010), $D B H$ is the diameter at breast height $(1.3 \mathrm{~m})$, expressed by $\mathrm{cm}$.

Understory was harvested by uprooting in three $1 \mathrm{~m} \times 1 \mathrm{~m}$ subplots in each plot in July when the understory biomass peaked. The samples were washed in floating water in the lab then. Three $1 \mathrm{~m} \times 1 \mathrm{~m}$ collectors set in a similar equilateral triangle shape were used to collect monthly litterfall in each plot. All samples were dried to constant weight at $65^{\circ} \mathrm{C}$. The annual biomass of understory is equal to annually formed biomass because the understory is newly formed every year.

\section{Net ecosystem production (NEP)}

The annual $\mathrm{CO}_{2}$ flux of RS and source components are calculated as follows (eq. 8):

$R_{\text {annual }}=\sum_{i=1}^{12} R_{i} \times 10^{-6} \times 3600 \times 24 \times 30(29 / 31) \times 10^{-6}$ where $R_{\text {annual }}$ is the annual $\mathrm{CO}_{2}$ flux of RS and its components $\left(\mathrm{t} \mathrm{CO}_{2} \mathrm{ha}^{-1} \mathrm{a}^{-1}\right) ; R_{i}$ is the mean monthly respiration rates of RS and its components $\left(\mu \mathrm{mol} \mathrm{m} \mathrm{m}^{-2} \mathrm{~s}^{-1}\right)$; the first $10^{-6}$ is the unit conversion of $1 \mu \mathrm{mol}$ to $1 \mathrm{~mol}$ while the second $10^{-6}$ is the unit conversion from $1 \mathrm{~g} \mathrm{CO}_{2}$ to $1 \mathrm{t} \mathrm{CO}_{2} ; 1$ day $=3600 \times 24 \mathrm{~s} ; 30(29 / 31)$ are the 
days of each month.

In forest ecosystems, NEP is determined by the balance between NPP of vegetation and heterotrophic respiration $(\mathrm{RH})$ of soil (Lee et al. 2003, Luo \& Zhou 2006):

$$
N E P=N P P-R_{h}
$$

Because total $R_{S}$ is the sum of autotrophic (RR) and RH, therefore, in our study, based on a year scale, $N E P$ was calculated (Luo \& Zhou 2006):

$$
N E P=N P P-\left(R S_{\text {annual }}-R R_{\text {annual }}\right)
$$

where $N P P$ is the net primary production $(\mathrm{t}$ $\mathrm{CO}_{2} \mathrm{ha}^{-1} \mathrm{a}^{-1}$ ), which was obtained as the sum of annual $\mathrm{C}$ from biomass, litterfall and vegetation; $R R_{\text {annual }}$ and $R S_{\text {annual }}$ are the annual $\mathrm{CO}_{2}$ flux $\left(\mathrm{t} \mathrm{CO}_{2} \mathrm{ha}^{-1} \mathrm{a}^{-1}\right)$ of RR and $\mathrm{RS}$, respectively.

\section{Root carbon use efficiency}

Carbon use efficiency is an important parameter for comparing carbon cycle variability among ecosystems (Ryan et al. 1997). Root is an important part in forest ecosystem and less intensive studied. In this study, RCUE was calculated using an indirect method (Chen et al. 2008a, Raich \& Nadelhoffer 1989):

$$
\begin{aligned}
& R C U E=1-R R_{\text {anпual }} / T B C A \\
& T B C A=R S_{\text {anпиа }}-L F+\Delta C_{b}
\end{aligned}
$$

where $T B C A$ is the total belowground carbon allocation based on a year scale, $L F$ is the annual litterfall, $\Delta C_{b}$ is the changes of belowground carbon pools (including litter layer, mineral layer, root layer). $\Delta C_{b}$ is assumed to be zero in the stable forest (Raich \& Nadelhoffer 1989). Because the Moso bamboo forest remain dynamic balance all the time, $\Delta C_{b}$ is considered too small that it was ignored in the Moso bamboo forests (Zhou \& Jiang 2004). Therefore, RCUE can be expressed:
$R C U E=1-R R_{\text {annual }} /\left(R S_{\text {annual }}-L F\right)$

\section{Data analysis}

Data analysis was processed in R 3.1.2 ( $\mathrm{R}$ Core Team 2014). First, respiration rates, ST and SM from four collars (two collars for RM) were averaged for each plot, and the average rates represented each plot. Two-way factorial ANOVA analysis was processed to exam the effects of month, understory removal and their interactions on ST, SM and respiration rates at the level of 0.05 . Regression analysis was used to model the relationship between respiration rates and soil temperature and moisture. Exponential models were used to describe the relationships between RS and ST while linearly models were used to describe the relationship between RS and SM (Liu et al. 2011, Wu et al. 2014b):

$$
\begin{aligned}
& R S=a \times e^{b \times S T} \\
& R S=a \times S M+b
\end{aligned}
$$

where $R S$ is the measured soil $\mathrm{CO}_{2}$ rates or its component respiration rates $\left(\mu \mathrm{mol} \mathrm{CO}_{2} \mathrm{~m}^{-2}\right.$ $\left.\mathrm{s}^{-1}\right), S T\left({ }^{\circ} \mathrm{C}\right)$ and $S M(\%)$ are the measured soil temperature and moisture at $5 \mathrm{~cm}$ depth, respectively, and $a$ and $b$ are fitted coefficients.

Temperature sensitivity $\left(Q_{10}\right)$, which is related to the increase in the RS rate at $10^{\circ} \mathrm{C}$ intervals in temperature, was calculated from $R S_{S T+10} / R S_{S T}$. Although $Q_{10}$ can well describe the temperature sensitivity of RS, it is a result of many processes, such as the changes of carbohydrates, root biomass, root activity, soil nutrient availability and litter biomass (Lee \& Jose 2003, Pregitzer et al. 2000, Ryan et al. 1996, Yan et al. 2006), but the high correlations between RS and ST and SM mask these direct effects on $R_{S}$ (Kuzyakov \& Gavrichkova 2010). As a result, Wu et al. (2014a) applied a two-factor regression (including ST and SM) to calculate $Q_{10}$, while most of the studies use soil temperature only (Liu et al. 2011, Yuste 
et al. 2003). In this study, despite there was a strong relationship between RS and SM (see result part) like many other studies (Liu et al. 2011, Wang et al. 2011b), to make the $Q_{10}$ comparable to most of the studies, ST was only used to calculate $Q_{10}$ as following (Yuste et al. 2003):

$$
Q_{10}=a \times e^{b \times(S T+10)} / a \times e^{b \times S T}=e^{10 b}
$$

where $b$ is taken from formula (14). For each treatment, the $Q_{10}$ was calculated based on monthly RS and ST in each plot.

\section{Results}

During the study period, regardless of the management, ST, SM, RS, RR, RL and RM varied greatly with the seasons (Fig. 1, 2, Table 1). RS in the stand $\mathrm{AH}$ ranged from 0.60 $\mu \mathrm{mol} \mathrm{CO} \mathrm{m}^{-2} \mathrm{~s}^{-1}$ in February to $4.24 \mu \mathrm{mol} \mathrm{CO}_{2}$ $\mathrm{m}^{-2} \mathrm{~s}^{-1}$ in June with an annual average of 2.27 $\mu \mathrm{mol} \mathrm{CO} \mathrm{m}^{-2} \mathrm{~s}^{-1}$, while RS in the stand HW changed from $0.76 \mu \mathrm{mol} \mathrm{CO}_{2} \mathrm{~m}^{-2} \mathrm{~s}^{-1}$ in February to $4.42 \mu \mathrm{mol} \mathrm{CO} \mathrm{m}^{-2} \mathrm{~s}^{-1}$ in June with an annual average of $2.44 \mu \mathrm{mol} \mathrm{CO} \mathrm{m}^{-2} \mathrm{~s}^{-1}$ (Fig. 2 a). There was no significant difference in total RS rates between the stand AH and HW ( $p=$ 0.18 , Table 1).

$\mathrm{RR}$ in the stand $\mathrm{AH}$ and $\mathrm{HW}$ peaked in July and August, respectively, and bottomed in February (Fig. 2 b). The annual mean rate was $0.78 \mu \mathrm{mol} \mathrm{CO} \mathrm{m}^{-2} \mathrm{~s}^{-1}$ for the stand $\mathrm{AH}$ and $0.73 \mu \mathrm{mol} \mathrm{CO}_{2} \mathrm{~m}^{-2} \mathrm{~s}^{-1}$ for the stand $\mathrm{HW}$, and they were not significantly different $(p=$
0.219, Table 1). Similarly, the highest rates of $\mathrm{RL}$ occurred in June for the stand $\mathrm{AH}$ and $\mathrm{Au}-$ gust for the stand HW, while the lowest rates were found in February for both stands (Fig. 2 c). No significant difference was observed in the annual average rates between the two stand (0.52 and $0.53 \mu \mathrm{mol} \mathrm{CO} \mathrm{C}^{-2} \mathrm{~s}^{-1}$, respectively, $p=0.909)$.

There was a similar changing pattern in RM between the two stands (Fig. 2 d). The maximum rate was found in June while the minimum rate occurred in February for both stands. $\mathrm{RM}$ of the stand $\mathrm{AH}$ was always higher than that of the stand HW. Annually, on average, $\mathrm{RM}$ was $0.88 \mu \mathrm{mol} \mathrm{CO}_{2} \mathrm{~m}^{-2} \mathrm{~s}^{-1}$ for the stand $\mathrm{AH}$, and it was lower than that for the stand HW $\left(1.18 \mu \mathrm{mol} \mathrm{CO} \mathrm{m}^{-2} \mathrm{~s}^{-1}, p=0.001\right)$.

$\mathrm{RS}, \mathrm{RR}, \mathrm{RL}$ and RM were exponentially related to the ST at $5 \mathrm{~cm}$ depth for both stands (Fig. 3). ST could explain $29 \%$ to $89 \%$ variations in the respiration rates (Table 2). $Q_{10}$ values of RS, RR, RL and RM were 1.82, 1.29, 1.91 and 2.21 for the stand $\mathrm{AH}$, respectively, and $1.77,1.89,1.39$ and 2.19 for the stand HW. $\mathrm{RS}, \mathrm{RR}, \mathrm{RL}$ and RM were linearly related to $\mathrm{SM}$ at $5 \mathrm{~cm}$ depth (Fig. 3), and SM could explain $31 \%$ to $85 \%$ of these seasonal variations (Table 2).

Annual $\mathrm{CO}_{2}$ flux of RS, RR, RL and $\mathrm{RM}$ were 31.6, 12.1, 7.2 and $12.3 \mathrm{t} \mathrm{CO}_{2} \mathrm{ha}^{-1}$ for the stand $\mathrm{AH}$, respectively, compared to 33.9 , 10.1, 7.3 and $16.5 \mathrm{t} \mathrm{CO}_{2} \mathrm{ha}^{-1}$ for the stand HW (Table 3).

Annual $\mathrm{CO}_{2}$ flux of $\mathrm{RM}$ for the stand $\mathrm{AH}$ was significantly lower than that of the stand HW $(p=0.003)$, while there were no significant

Table 1 Two-way factorial ANOVA analysis of the effects of month, understory removal and their interactions on $\mathrm{ST}, \mathrm{SM}$ and respiration rates

\begin{tabular}{lcccccc}
\hline Time/treatment effects & $\mathrm{ST}$ & $\mathrm{SM}$ & $\mathrm{RS}$ & $\mathrm{RR}$ & $\mathrm{RL}$ & $\mathrm{RM}$ \\
\hline Month & $<0.001$ & $<0.001$ & $<0.001$ & $<0.001$ & 0.007 & $<0.001$ \\
$\begin{array}{l}\text { Understory removal } \\
\begin{array}{l}\text { Month } \times \text { understory } \\
\text { removal }\end{array}\end{array}$ & 0.002 & 0.36 & 0.18 & 0.219 & 0.909 & $<0.001$ \\
\hline
\end{tabular}



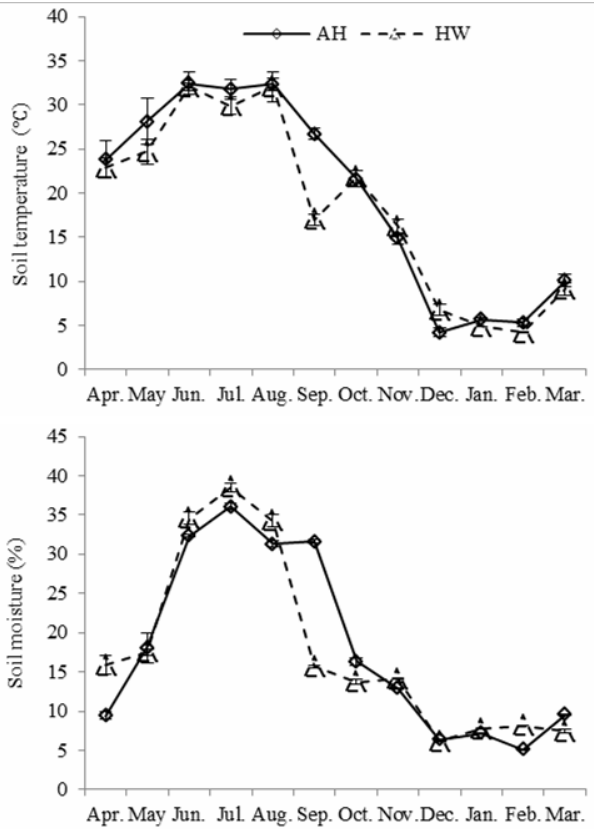

Figure 1 Seasonal changes in soil temperature $\left({ }^{\circ} \mathrm{C}\right)$ and soil moisture (\%) at $5 \mathrm{~cm}$ depth.

The bars mean the standard error $(n=3)$. AH and HW represent the application of herbicides and hand-weeded stands difference in RS, RR and RL (all $p>0.05$ ). In the stand $\mathrm{AH}, \mathrm{RR}, \mathrm{RL}$ and $\mathrm{RM}$ contributed $38 \%, 23 \%$ and $39 \%$ to total RS, respectively, while RR, RL and RM contributed 30\%, 21\% and $49 \%$ to RS in the stand HW. They were not statistically different (all $p>0.05$ ).

Litter represented an import carbon pool of $14.1 \mathrm{t} \mathrm{CO}_{2} \mathrm{ha}^{-1}$ for stand AH (Table 3), which was significantly higher than that of stand HW (9.0 t $\left.\mathrm{CO}_{2} \mathrm{ha}^{-1}, p<0.001\right)$. In contrast, bamboo NPP and RCUE of stand AH was significantly lower than that of the stand HW $(p=0.013$ and 0.021). NEP of the two stands was similar (21.9 and $21.3 \mathrm{t} \mathrm{CO}_{2} \mathrm{ha}^{-1}$, respectively).

\section{Discussion}

\section{Effects of understory removal on RS}

Understory removal represent an important management practice in the Moso bamboo forests. Understory removed by hand-weeded and herbicide application was widely used due to easy-to-operate. In this study, the effects of

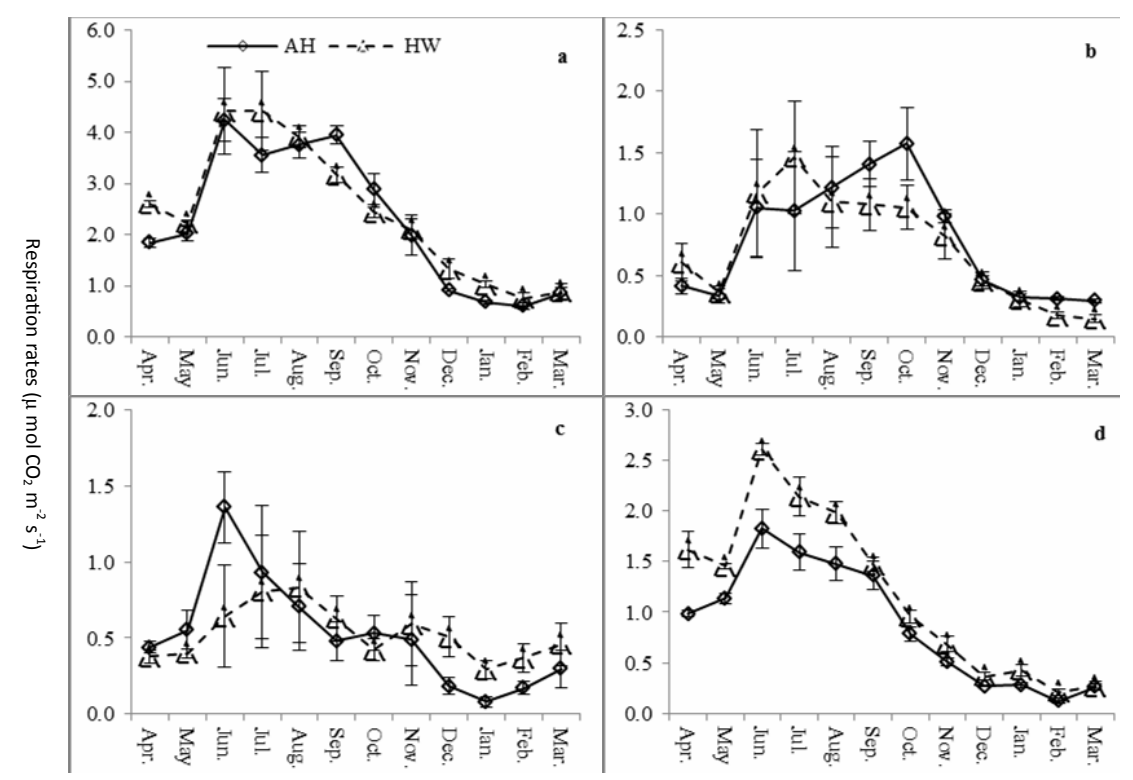

Figure 2 Seasonal changes of total soil respiration (a), root respiration (b), litter respiration (c) and soil organic matter derived respiration (d) $\left(\mu \mathrm{mol} \mathrm{CO} \mathrm{C}^{-2} \mathrm{~s}^{-1}\right)$. The bars mean the standard error $(\mathrm{n}=3)$. $\mathrm{AH}$ and HW represent the application of herbicides and hand-weeded stands. 
Table 2 The coefficients (a) of the relationships between soil respiration $\left(\mu \mathrm{mol} \mathrm{m} \mathrm{m}^{-2} \mathrm{~s}^{-1}\right)$ and soil temperature $\left({ }^{\circ} \mathrm{C}\right)$, soil moisture $(\%)$

\begin{tabular}{|c|c|c|c|c|c|c|c|c|}
\hline Variables & Stands & Components & $\mathrm{a}$ & $p$ & $\mathrm{~b}$ & $p$ & $\mathrm{R}^{2}$ & $Q_{10}$ \\
\hline \multirow{8}{*}{$\begin{array}{l}\text { Soil } \\
\text { temperature }\end{array}$} & \multirow{5}{*}{ I } & $\mathrm{RS}$ & 0.564 & $<0.001$ & 0.060 & $<0.001$ & 0.82 & 1.82 \\
\hline & & RR & 0.384 & $<0.001$ & 0.025 & $<0.001$ & 0.29 & 1.29 \\
\hline & & RL & 0.100 & $<0.001$ & 0.065 & $<0.001$ & 0.59 & 1.91 \\
\hline & & $\mathrm{RM}$ & 0.140 & $<0.001$ & 0.079 & $<0.001$ & 0.89 & 2.21 \\
\hline & & $\mathrm{RS}$ & 0.719 & $<0.001$ & 0.057 & $<0.001$ & 0.81 & 1.77 \\
\hline & \multirow{3}{*}{ II } & RR & 0.203 & $<0.001$ & 0.052 & $<0.001$ & 0.37 & 1.68 \\
\hline & & RL & 0.271 & $<0.001$ & 0.033 & $<0.001$ & 0.36 & 1.39 \\
\hline & & $\mathrm{RM}$ & 0.206 & $<0.001$ & 0.078 & $<0.001$ & 0.85 & 2.19 \\
\hline \multirow{8}{*}{$\begin{array}{l}\text { Soil } \\
\text { moisture }\end{array}$} & \multirow{5}{*}{ I } & $\mathrm{RS}$ & 0.110 & $<0.001$ & 0.292 & 0.110 & 0.84 & \\
\hline & & RR & 0.043 & $<0.001$ & 0.144 & 0.368 & 0.50 & \\
\hline & & RL & 0.024 & $<0.001$ & 0.062 & 0.590 & 0.39 & \\
\hline & & RM & 0.046 & $<0.001$ & -0.023 & 0.767 & 0.85 & \\
\hline & & $\mathrm{RS}$ & 0.108 & $<0.001$ & 0.520 & 0.022 & 0.76 & \\
\hline & \multirow{3}{*}{ II } & RR & 0.032 & $<0.001$ & 0.161 & 0.352 & 0.31 & \\
\hline & & RL & 0.019 & $<0.001$ & 0.230 & 0.007 & 0.45 & \\
\hline & & $\mathrm{RM}$ & 0.020 & $<0.001$ & 0.063 & 0.846 & 0.82 & \\
\hline
\end{tabular}

Note. AH and HW represent the application of herbicides and hand-weeded stands. RS, RR, RL and RM represent total soil respiration, root respiration, litter respiration and soil organic matter derived respiration, respectively.

Table 3 The carbon flux components and net ecosystem primary production $\left(\mathrm{t} \mathrm{CO}_{2} \mathrm{ha}^{-1}\right)$

\begin{tabular}{lccccccccc}
\hline Stand & RS & RR & RL & RM & litter & Understory & NPP & NEP & RCUE \\
\hline AH & $31.6 \pm 1.7^{\mathrm{a}}$ & $12.1 \pm 0.7^{\mathrm{a}}$ & $7.2 \pm 1.2^{\mathrm{a}}$ & $12.3 \pm 0.3^{\mathrm{a}}$ & $14.1 \pm 0.5^{\mathrm{b}}$ & $0.9 \pm 0.1^{\mathrm{a}}$ & $26.4 \pm 0.1^{\mathrm{a}}$ & $21.9 \pm 2.0^{\mathrm{a}}$ & $30.6 \pm 6.3^{\mathrm{a}}$ \\
HW & $33.9 \pm 2.0^{\mathrm{a}}$ & $10.1 \pm 0.7^{\mathrm{a}}$ & $7.3 \pm 1.5^{\mathrm{a}}$ & $16.5 \pm 0.5^{\mathrm{b}}$ & $9.0 \pm 0.2^{\mathrm{a}}$ & $3.0 \pm 0.4^{\mathrm{b}}$ & $33.2 \pm 3.5^{\mathrm{b}}$ & $21.3 \pm 4.8^{\mathrm{a}}$ & $58.8 \pm 4.9^{\mathrm{b}}$ \\
\hline
\end{tabular}

Note. AH and HW represent the application of herbicides and hand-weeded stands. RS, RR, RL and RM represent total soil respiration, root respiration, litter respiration and soil organic matter derived respiration, respectively. BNPP is bamboo net primary production, NEP is net ecosystem production and RCUE is the root carbon use efficiency.

hand-weeded and herbicide application were compared. Between the two stands, there was no significant difference in total RS, RR and $\mathrm{RL}$, however, $\mathrm{RM}$ differed significantly ( $p=$ $0.001)$. This may be due to the application of herbicide in the AH stand. RM mainly comes from soil organic matter decomposed by soil microbes and fauna (Li et al. 2006, Subke et al. 2006). Although there was no direct evidence about the effects of the application of herbicide on microbial biomass in this study, previous studies suggested that herbicide lowered the microbial biomass carbon and had a long-lasting negative effect on soil microbial biomass, which directly led a decrease in respiration rates (Perucci et al. 2000).
Annual $\mathrm{CO}_{2}$ from RS were $31.6 \mathrm{t} \mathrm{CO}_{2} \mathrm{ha}^{-1}$ $\mathrm{a}^{-1}$ for stand $\mathrm{AH}$ and $33.9 \mathrm{t} \mathrm{CO}_{2} \mathrm{ha}^{-1} \mathrm{a}^{-1}$ for the stand $\mathrm{HW}$, which were close to the soil $\mathrm{CO}_{2}$ flux in Moso bamboo forests in Hunan Province, China (Table 4) (Fan et al. 2009a), Cunninghamia lanceolata forests in subtropical China (Wu et al. 2014b) and the aspen forest in boreal area (Gaumont-Guay et al. 2009).

The value was higher than the reported $\mathrm{CO}_{2}$ flux in the Pleioblastus amarus bamboo (Tu et al. 2013), Eucalyptus forests in North Australia (Chen et al. 2003) and Quercus forests (Lee et al. 2010). On the other hand, the values was lower than that of Moso bamboo forest in Zhejiang and Fujian Province (Song et al. 2013, Wang et al. 2011a), natural and planted 
Castanopsis kawakamii forests in subtropical China (Yang et al. 2007) and black forest (Gaumont-Guay et al. 2009). These great variations in RS flux mainly resulted from (1) forest types and stand structure because these variables strongly influence $\mathrm{C}$ allocation patterns (Wang et al. 2001); (2) belowground metabolism because RS was always correlated to fine root and root production (Coleman et al. 2000, Pregitzer et al. 1998); (3) allocation of new plant photosynthesis to roots (Högberg et al. 2001); (4) leaf area and primary productivity (Högberg et al. 2001, Rey et al. 2002); (5) climate conditions (Raich \& Schlesinger 1992, Wang et al. 2010).

\section{Contribution of source components of RS to total RS}

Previous studies has demonstrated that the contribution of RR to total RS varies significantly from $10 \%$ to $90 \%$ (Hanson et al. 2000) due to the variability to methodological issues, forest types, soil conditions, stand age, forest structure and forest management (Hanson et al. 2000, Li et al. 2008, Rey et al. 2002). Hanson et al. (2000) further pointed out that RR contributed $30 \%-80 \%$ to total RS with a world average of $46 \%$ in forest ecosystems. Similarly, Chen et al. (2008b) estimated the contribution of RR to total RS amounted from $10 \%$ to $65 \%$ with an average of $35 \%$ in Chinese forest ecosystems. In this study, RR contributed 30\% and $38 \%$ to total RS, which lied in the ranged for these reported values and was highly comparable to the average of China's forests. In addition, the contribution of each component to total RS was not statistically significant between the two stands, indicating that compared to traditional hand-weeded, application of herbicides did not change these contributions.

Trenching is a widely used approach due to its easy-to-operation and low cost that allows a partitioning of RS to explore the components of soil $\mathrm{CO}_{2}$ efflux (Hanson et al. 2000). However, there are some well-known problems associated with the trenching approach, such 12 as the decomposition of remaining dead roots and the increase of SM in the trenched plots (Hanson et al. 2000, Wang \& Yang 2007). To overcome these problems, Ewel et al. (1987) addressed these problems by measuring RS four month after the trenching and sampled the fine roots in the trenched subplots. Similarly, some scientists recommended that the starting measurement of soil $\mathrm{CO}_{2}$ flux was not conducted until the flux in the trenched subplots remained stable, which always took 2-9 months (Hanson et al. 2000, Wang \& Yang 2007, Yan et al. 2015). Therefore, to reduce the bias, the respiration due to root decomposition in the trenched plots should be removed. In this study, although soil $\mathrm{CO}_{2}$ flux was measured one month after the trenching, to minimize the effects of residual roots, equation (1) - (5) were used to exclude the $\mathrm{CO}_{2}$ flux from the decomposition of dead roots.

\section{Influence of environmental factors on RS}

ST and SM are two of the most important environmental factors driving the seasonal and diurnal changes of RS (Davidson et al. 1998, Tang et al. 2015, Wang et al. 2010), and RS is highly sensitive to ST (Davidson \& Janssens 2006, Wang et al. 2011a). This study confirmed these conclusions that ST and SM were the main driving forces of the seasonality of source components of RS and total RS (Fig. 3 and 4). This study is still consistent with the results from Liu et al. (2011) and Tang et al. (2015), who observed a strong relationship between RS and ST, RS and SM in the Moso bamboo forests in the subtropical China. However, the degree of correlation $\left(\mathrm{R}^{2}\right)$ between components of RS and ST and SM varied.

Similar results were found in other studies in Moso bamboo forests that ST could explain $86 \%$ variations of seasonal changes of $\mathrm{RS}$, while ST could only explain $46 \%$ and $51 \%$ to variation of RR and RL (Tang et al. 2015). SM could explain $78 \%$ variation of seasonal changes of RS and $55 \%$ and $41 \%$ variation of RR and RL (Tang et al. 2015). This discrepan- 
Table 4 Annual $\mathrm{CO}_{2}$ flux $\left(\mathrm{t} \mathrm{CO}_{2} \mathrm{ha}^{-1} \mathrm{a}^{-1}\right)$, ratio of $\mathrm{RR} / \mathrm{RS}$, net ecosystem production (NEP, $\left.\mathrm{t} \mathrm{CO}_{2} \mathrm{ha}^{-1} \mathrm{a}^{-1}\right)$, $\mathrm{Q}_{10}$ of RS in different forest ecosystems

\begin{tabular}{|c|c|c|c|c|c|c|c|}
\hline Forest type & $\begin{array}{l}\text { Study } \\
\text { area }\end{array}$ & Method & $\begin{array}{l}\text { Annual } \\
\mathrm{CO}_{2} \text { flux }\end{array}$ & $\begin{array}{l}\mathrm{RR} / \mathrm{RS} \\
(\%)\end{array}$ & NEP & $\begin{array}{l}Q_{10} \text { of } \\
\mathrm{RS}\end{array}$ & Reference \\
\hline Moso bamboo forest & $\mathrm{SC}$ & $\mathrm{T}$ & 31.6 & 38.3 & 21.90 & 1.82 & This study \\
\hline Moso bamboo forest & $\mathrm{SC}$ & $\mathrm{T}$ & 33.9 & 29.8 & 21.30 & 1.77 & This study \\
\hline Moso bamboo forest & $\mathrm{SC}$ & $\mathrm{T}$ & 33.9 & 28.3 & - & - & Fan et al. (2009a) \\
\hline Moso bamboo forest & $\mathrm{SC}$ & - & 52.9 & - & - & 2.18 & Song et al. (2013) \\
\hline $\begin{array}{l}\text { Intensively managed Moso } \\
\text { bamboo forest }\end{array}$ & $\mathrm{SC}$ & - & 56.8 & - & - & 2.46 & Liu et al. (2011) \\
\hline $\begin{array}{l}\text { Conventionally managed Moso } \\
\text { bamboo forest }\end{array}$ & $\mathrm{SC}$ & - & 41.2 & - & - & 3.24 & Liu et al. (2011) \\
\hline Moso bamboo forest & $\mathrm{SC}$ & & 49.9 & - & - & 2.08 & Wang et al. (2011a) \\
\hline Pleioblastus amarus bamboo & $\mathrm{SC}$ & $\mathrm{T}$ & 15.7 & 49.1 & - & 2.87 & Tu et al. (2013) \\
\hline Cunninghamia lanceolata & $\mathrm{SC}$ & $\mathrm{T}$ & 16.7 & 33.0 & - & 2.08 & Tian et al. (2011) \\
\hline Pinus massoniana & $\mathrm{SC}$ & $\mathrm{T}$ & 62.0 & 44.5 & - & 2.38 & Han et al. (2011) \\
\hline Quercus & NT & TG & & 53.0 & - & 2.95 & Högberg et al. (2009) \\
\hline Castanopsis carlesii & $\mathrm{SC}$ & $\mathrm{T}$ & 45.1 & 35.1 & - & 2.41 & Wu et al. (2014b) \\
\hline Cunninghamia lanceolata & $\mathrm{SC}$ & $\mathrm{T}$ & 33.2 & 37.6 & - & 2.12 & Wu et al. (2014b) \\
\hline Setaria italica & $\mathrm{SC}$ & $\mathrm{T}$ & - & 67.3 & 5.16 & - & Li et al. (2010a) \\
\hline Natural Castanopsis kawakamii & $\mathrm{SC}$ & $\mathrm{T}$ & 41.2 & 47.6 & 15.20 & - & Yang et al. (2007) \\
\hline Planted Castanopsis kawakamii & $\mathrm{SC}$ & $\mathrm{T}$ & 48.6 & 42.5 & 27.60 & - & Yang et al. (2007) \\
\hline Cunninghamia lanceolata & $\mathrm{SC}$ & $\mathrm{T}$ & 23.8 & 40.2 & 13.50 & - & Yang et al. (2007) \\
\hline $\begin{array}{l}\text { Eucalyptus tetrodonta, } \\
\text { Eucalyptus miniata }\end{array}$ & NA & - & 20.9 & - & 13.90 & - & Chen et al. (2003) \\
\hline Abies holophylla & CT & $\mathrm{T}$ & 28.6 & 34.0 & 4.30 & & Lee et al. (2010) \\
\hline Quercus & CT & $\mathrm{T}$ & 22.3 & 31.0 & 3.60 & & Lee et al. (2010) \\
\hline Aspen forest & $\mathrm{BF}$ & $\mathrm{EC}$ & 30.3 & - & 3.80 & 3.20 & Gaumont-Guay et al. (2009) \\
\hline Black forest & $\mathrm{BF}$ & $\mathrm{EC}$ & 20.8 & - & 2.90 & 2.50 & Gaumont-Guay et al. (2009) \\
\hline
\end{tabular}

Note. Abbreviations: SC - Subtropical China, NT - Northern temperate deciduous forest, NA - North Australia, CT cool-temperate forest, BF - Boreal forest, T - Trenching, TG - Tree-girdling, EC - eddy-covariance technique.

cy may result from different response mechanisms of source components of RS to ST and SM. For instance, temperature can affect photosynthetic C supply for photosynthesis, thereby affecting the carbon use for RR (Kaspar \& Bland 1992, Tang et al. 2005). ST and SM affect RM by decomposition and oxidation of soil organic matter, the movement of air in soil, activity and abundance of microorganisms (Davidson \& Janssens 2006, Luo \& Zhou 2006). However, it should be aware that besides ST and SM, other biotic factors, such as carbohydrates, root biomass, root activity, soil nutrient availability and litter biomass, had significant effects on RS (Lee \& Jose 2003, Pregitzer et al. 2000, Ryan et al. 1996, Yan et al. 2006), but the high correlations between RS and ST and SM mask these direct effects on RS (Kuzyakov \& Gavrichkova 2010).

$Q_{10}$ has been widely used to describe the temperature dependence of RS, which is calculated calculated from a series of measured RS values over a time period while soil temperature changes (Ma et al. 2014, Rey et al. 2002).

Based on a meta-analysis of the global soil respiration rates, recent studies show that $Q_{10}$ value varies from 1.1 to 6.7 , depending on the measured ST of different depths (Bahn et al. 2010, Chen et al. 2008b, Song et al. 2014). In this study, $Q_{10}$ ranged from 1.29 to 2.21 (Table 2), which lies in the lower range of China's forests (1.33-5.53) and were lower the average 


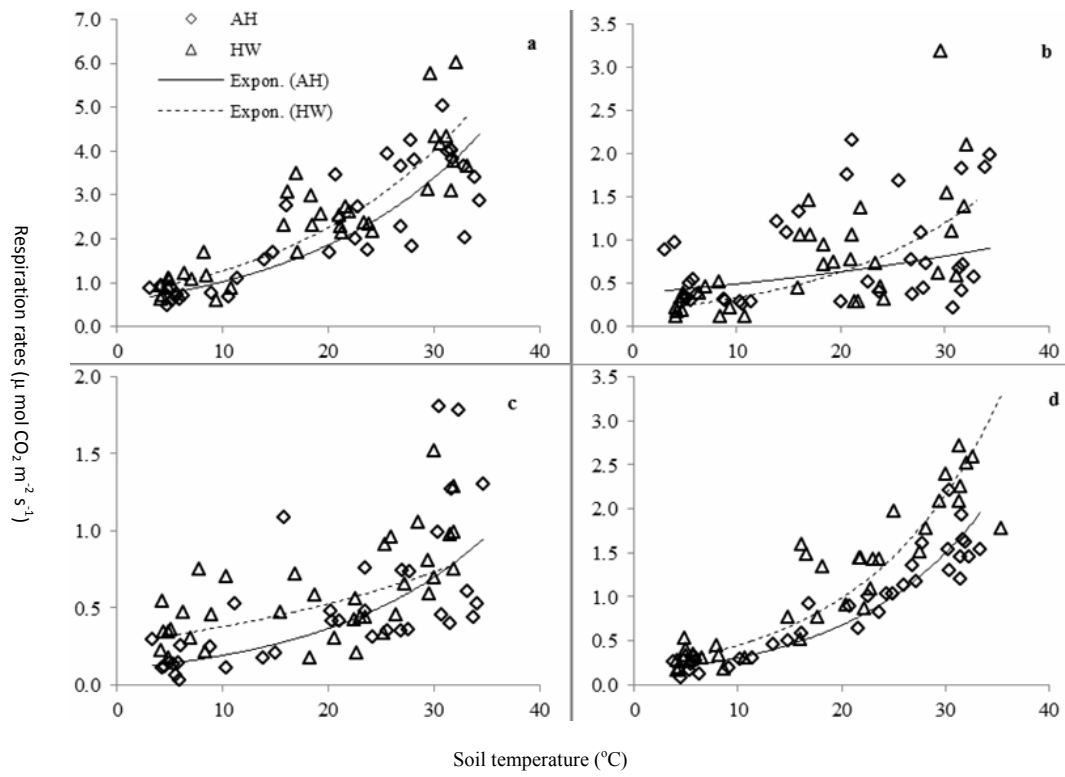

Figure 3 The relationship between total soil respiration (a), root respiration (b), litter respiration (c) and soil organic matter derived respiration (d) and soil temperature. $\mathrm{AH}$ and HW represent the application of herbicides and hand-weeded stands. The coefficients are shown in Table 2.

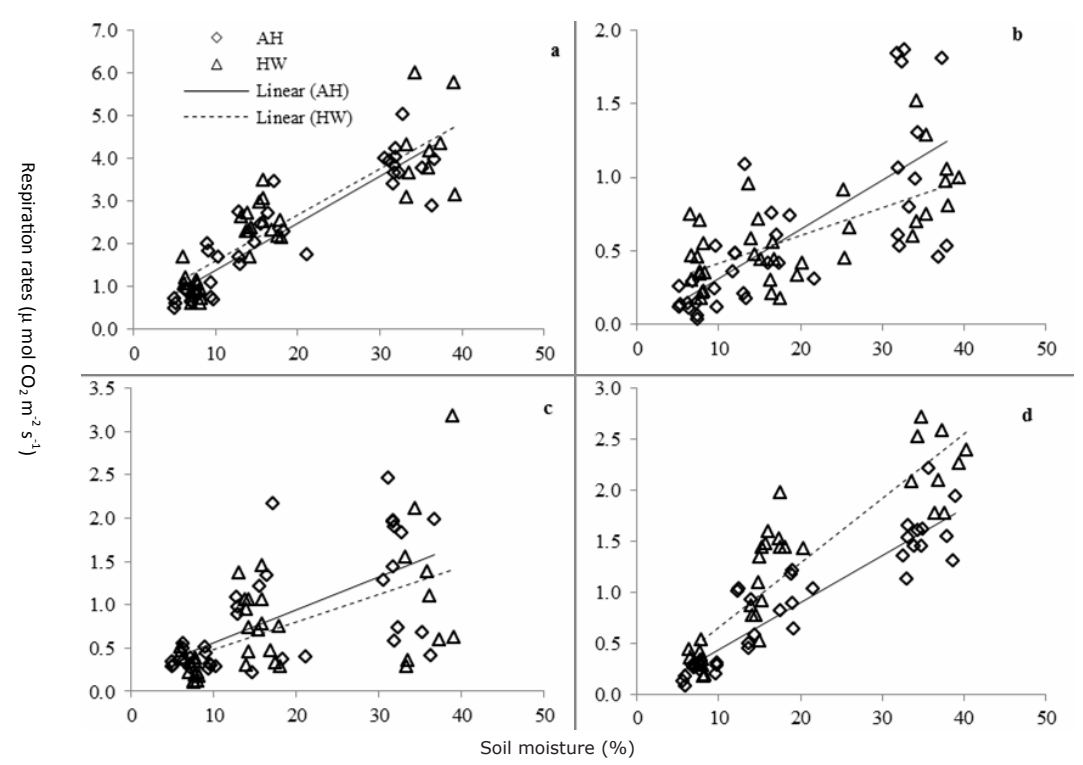

Figure 4 The relationship between total soil respiration (a), root respiration (b), litter respiration (c) and soil organic matter derived respiration (d) and soil temperature. AH and HW represent the application of herbicides and hand-weeded stands. The coefficients are shown in Table 2. 
(2.65) (Chen et al. 2008b), suggesting that soil $\mathrm{CO}_{2}$ flux in Moso bamboo forests is less sensitive to ST changes and exerts less soil $\mathrm{CO}_{2}$ to future climate change compared other forest types in China. $Q_{10}$ of this study was compared to Moso bamboo forests in Wangmulin natural reserve (2.08, Wang et al. 2011a), and the average $Q_{10}$ of bamboo forests in China (2.1, Song et al. 2014).

In both stands, $Q_{10}$ of RM was highest compared to other components and total RS. This highlights the importance of RM in regulating $Q_{10}$ of RS, which is consistent with other studies in subtropical forests (Li et al. 2011, Luan et al. 2011), as well as Moso bamboo forests (Tang et al. 2015). However, disagreements among the studies still remain. Boone et al. (1998) estimated $Q_{10}$ value was 2.5 for heterotrophic respiration and 4.6 for RR in a temperate forest. On the other hand, Luan et al. (2011) found a $Q_{10}$ value of 3.93 for heterotrophic respiration, which was significantly higher than that of RR (2.78). While Yan et al. (2015) found no difference in $Q_{10}$ values between heterotrophic respiration (2.13) and RR (1.90). However, the variability of $Q_{10}$ of different components of RS will affect the accumulative soil $\mathrm{CO}_{2}$ flux across the stands. Thus, partitioning of RS and their $Q_{10}$ values should be required in ecosystem carbon cycling models of future climate change (Luan et al. 2011).

\section{Net ecosystem production}

NEP of the terrestrial ecosystems is a key process when managing the $\mathrm{C}$ cycle (Harmon et al. 2004). NEP of the stand AH and HW were 21.9 and $21.1 \mathrm{t} \mathrm{CO}_{2} \mathrm{ha}^{-1}$, respectively, indicating that the both Moso bamboo stands were $\mathrm{C}$ sinks in current climate change. The results were higher than Eucalyptus tetrodonta (Chen et al. 2003), Abies holophyll, Quercus (Lee et al. 2010), Aspen forest and Black forest (Gaumont-Guay et al. 2009), but lower than the planted Castanopsis kawakamii (Table 4) (Yang et al. 2007). These great differences may result from tree species and their biological characteristics, soil conditions, and different method applications (Malhi et al. 1999, Xiao et al. 2010). For instance, the estimation of NEP from component process approach generate greater error compared to the eddy-covariance flux measurement (Malhi et al. 1999). However, in this study, soil $\mathrm{CO}_{2}$ measurement was conducted in one-month interval, but this is somehow limited due to the significant changes of environmental factors. This can be overcome by increasing the measurement intervals (e.g. bio-weekly or weekly). It also calls for the installation of continuous measurement technique with a high time resolution (e.g. $1 \mathrm{~h}$ ) in the field. Because of the special biological characteristics of Moso bamboo forests, longterm measurements including at least "onyear" and "off-year" are recommended, which could improve our understanding of role of Moso bamboo forests in global carbon cycling. Root carbon use efficiency

Carbon use efficiency is an important ecological variable to describe the capacity of forest to transfer the carbon from atmosphere to biomass (Chambers et al. 2004), which includes important parameters to compare carbon cycle variability among ecosystems (Ryan et al. 1997). Compared to the aboveground carbon allocation and CUE, the allocation of belowground carbon and RCUE is one of the most important but least well quantified carbon flux in terrestrial ecosystems (Tan et al. 2010). In most of the carbon budget models, the RCUE is assumed to be 50\% (Giardina et al. 2003, Law et al. 1999) although some researches propose that the NPP decrease with the increase of age while the ecosystem respiration increase with the age, which could lead to the decrease of total forest carbon use efficiency (Ryan et al. 1997). However, how the RCUE changes with the stand development is still unclear. In our study, RCUE was 30.6\% for the stand $\mathrm{AH}$, which was comparable to the young jack pine forest 27\% (Ryan et al. 1997), while these values were lower than that 
of the stand HW (58.8\%). These results indicated that the constant RCUE (50\%) in Moso bamboo forest was not available and different management practices could affect RCUE. Zhu (2013) attributed these differences to the variations in ecosystems, forest types, species and ontogeny of plant development. However, the differences in RCUE among different forest ecosystems might be partly attributed to different methods.

For example, CUE estimated from the biometrical approach was $42 \%$ while CUE estimated from meteorological approach was $54 \%$ in a northern hardwood forest over five-year measurement (Curtis et al. 2005). Therefore, the selection of appropriate approach to measure RCUE could improve the estimate accuracy.

\section{Conclusions}

One-year field measurements of RS and its source components were conducted in two managed Moso bamboo forests. In both stands, RS and source components shown significantly seasonal changes, and ST and SM were the main driving forces to the seasonal changes.

Compared to conventional hand-weeded, the application of herbicide had no significant effects on total RS, RR and RL, but significantly decreased RM. $Q_{10}$ values was highest for RM.

However, studies on the temperature sensitivity of each component of RS are limited, and no general agreement has been achieved.

Both stands act as carbon sinks in current climate change. RCUE varied significantly among the two stands, suggesting RCUE could be altered by different stand management practices. The constant CUE value of 50\% was not appropriate in Moso bamboo forests. However, this study was conducted in "on-year" Moso bamboo stand, due to special biological characteristics of Moso bamboo forests, longterm measurements including "on-year" and "off-year" are recommended to improve our understanding its role in global carbon cycling. 16

\section{Acknowledgements}

This study was supported by "948 project" of State Forest Administration (2013-4-70), special research fund of International Centre for Bamboo and Rattan (1632013010), Special Funds for Forestry Public Industry Research (201104008). The authors would like to thank Qingbiao $\mathrm{Xu}$ for carrying fieldwork and lab work, and Jin Yu, Chuxin Shen for support of fieldwork.

\section{References}

Bahn M., Reichstein M., Davidson E.A., Grunzweig J., Jung M., Carbone M.S., Epron D., Misson L., Nouvellon Y., Roupsard O., Savage K., Trumbore S.E., Gimeno C., Yuste J.C., Tang J., Vargas R., Janssens I.A., 2010. Soil respiration at mean annual temperature predicts annual total across vegetation types and biomes. Biogeosciences 7:2147-2157. DOI: 10.5194/bg-7-2147-2010.

Bond-Lamberty B., Thomson A., 2010. Temperature-associated increases in the global soil respiration record. Nature 464:579-582. DOI: 10.1038/nature08930.

Bond-Lamberty B., Wang C., Gower S.T., 2004. A global relationship between the heterotrophic and autotrophic components of soil respiration? Global Change Biology 10:1756-1766. DOI: 10.1111/j.13652486.2004.00816.x.

Boone R.D., Nadelhoffer K.J., Canary J.D., Kaye J.P., 1998. Roots exert a strong influence on the temperature sensitivity of soil respiration. Nature 396:570-572. DOI: $10.1038 / 25119$.

Brunner I., Bakker M.R., Björk R.G., Hirano Y., Lukac M., Aranda X., Børja I., Eldhuset T.D., Helmisaari H.S., Jourdan C., Konôpka B., López B.C., Miguel Pérez C., Persson H., Ostonen I., 2013. Fine-root turnover rates of European forests revisited: an analysis of data from sequential coring and ingrowth cores. Plant and Soil 362:357-372. DOI: 10.1007/s11104-012-1313-5.

Chambers J.Q., Tribuzy E.S., Toledo L.C., Crispim B.F., Higuchi N., dos Santos J., Araujo A.C., Kruijt B., Nobre A.D., Trumbore S.E., 2004. Respiration from a tropical forest ecosystem: Partitioning of sources and low carbon use efficiency. Ecological Applications 14:S72-S88. DOI: 10.1890/01-6012.

Chen G., Yang Y., Gao R., Xie J., Yang Z., Mao Y., 2008. Changes in belowground carbon allocation in a Chinese fir chronosequence in Fujian Province. Journal of Plant Ecology (Chinese version) 32:1285-1293 (in Chinese with English abstract). DOI: $10.3773 /$ j.issn.1005264x.2008.06.009.

Chen G., Yang Y., Lv P., Zhang Y., Qian X., 2008. Regional patterns of soil respiration in China's forests. 
Acta Ecologica Sinica 28:1748-1761 (In Chinese with English abstract).

Chen G.S., Yang Y.S., Guo J.F., Xie J.S., Yang Z.J., 2011. Relationships between carbon allocation and partitioning of soil respiration across world mature forests. Plant Ecology 212:195-206. DOI: 10.1007/s11258-0109814-x.

Chen X., Hutley L.B., Eamus D., 2003. Carbon balance of a tropical savanna of northern Australia. Oecologia 137:405-416. DOI: 10.1007/s00442-003-1358-5.

Chen X.G., Zhang X.Q., Zhang Y.P., Booth T., He X.H., 2009. Changes of carbon stocks in bamboo stands in China during 100 years. Forest Ecology and Management 258:1489-1496. DOI: 10.1016/j.foreco.2009.06.051.

China Green Foundation, 2008 Carbon sink afforestation projects metering and monitoring guidelines. Chinese Forestry Publisher, Beijing, pp 58-59.

Coleman M., Dickson R., Isebrands J., 2000. Contrasting fine-root production, survival and soil $\mathrm{CO} 2$ efflux in pine and poplar plantations. Plant and Soil 225:129139. DOI: $10.1023 / \mathrm{a}: 1026564228951$.

Curtis P., Vogel C., Gough C., Schmid H., Su H.B., Bovard B., 2005. Respiratory carbon losses and the carbon use efficiency of a northern hardwood forest, 1999-2003. New Phytologist 167:437-456. DOI.

Davidson E.A., Belk E., Boone R.D., 1998. Soil water content and temperature as independent or confounded factors controlling soil respiration in a temperate mixed hardwood forest. Global Change Biology 4:217-227. DOI: 10.1046/j.1365-2486.1998.00128.x.

Davidson E.A., Janssens I.A., 2006. Temperature sensitivity of soil carbon decomposition and feedbacks to climate change. Nature 440:165-173. DOI: 10.1038/ nature04514.

Davidson E.A., Verchot L.V., Cattânio J.H., Ackerman I.L., Carvalho J.E.M., 2000. Effects of soil water content on soil respiration in forests and cattle pastures of eastern Amazonia. Biogeochemistry 48:53-69. DOI: 10.1023/a:1006204113917.

DeLucia E.H., Drake J.E., Thomas R.B., Gonzalez-Meler M., 2007. Forest carbon use efficiency: is respiration a constant fraction of gross primary production? Global Change Biology 13:1157-1167. DOI: 10.1111/j.13652486.2007.01365.x.

Du H.Q., Zhou G.M., Fan W.Y., Ge H.L., Xu X.J., Shi Y.J., Fan W.L., 2010. Spatial heterogeneity and carbon contribution of aboveground biomass of moso bamboo by using geostatistical theory. Plant Ecology 207:131-139. DOI: 10.1007/s11258-009-9659-3.

Ewel K.C., Cropper.Jr W.P., Gholz H.L., 1987. Soil CO2 evolution in Florida slash pine plantations. II. Importance of root respiration. Canadian Journal of Forest Research 17:330-333. DOI: 10.1139/x87-055.

Fan S., Xiao F., Wang S., Guan F., Yu X., Shen Z., 2009. Soil respiration of Moso bamboo plantation in Huitong, Hu'nan Province. Acta Ecologica Sinica 29:5971-5977 (In Chinese with English abstract).
Fan S., Xiao F., Wang S., Su W., Yu X., Shen Z., 2009. Fine root biomass and turnover in Moso Bamboo plantation in Huitong Forest Station, Hunan Province. Scientia Silvae Sinicae 45:1-6 (In Chinese with English abstract).

$\mathrm{Fu}$ J., 2000. Moso bamboo in China. ABS Magazine 21:12-17.

Gaumont-Guay D., Black T.A., McCaughey H., Barr A.G., Krishnan P., Jassal R.S., Nesic Z., 2009. Soil CO efflux in contrasting boreal deciduous and coniferous stands and its contribution to the ecosystem carbon balance. Global Change Biology 15:1302-1319. DOI: 10.1111/j.1365-2486.2008.01830.x.

Giardina C.P., Ryan M.G., 2000. Evidence that decomposition rates of organic carbon in mineral soil do not vary with temperature. Nature 404:858-861. DOI: 10.1038/35009076.

Giardina C.P., Ryan M.G., Binkley D., Fownes J.H., 2003. Primary production and carbon allocation in relation to nutrient supply in a tropical experimental forest. Global Change Biology 9:1438-1450. DOI: 10.1046/j.13652486.2003.00558.x.

Högberg P., Bhupinderpal S., Löfvenius M.O., Nordgren A., 2009. Partitioning of soil respiration into its autotrophic and heterotrophic components by means of tree-girdling in old boreal spruce forest. Forest Ecology and Management 257:1764-1767. DOI: 10.1016/j.foreco.2009.01.036.

Högberg P., Nordgren A., Buchmann N., Taylor A.F.S., Ekblad A., Hogberg M.N., Nyberg G., Ottosson-Lofvenius M., Read D.J., 2001. Large-scale forest girdling shows that current photosynthesis drives soil respiration. Nature 411:789-792. DOI: 10.1038/35081058.

Han T.F., Zhou G.Y., Li Y.L., Liu J.X., Zhang D.Q., 2011. Partitioning soil respiration in lower subtropical forests at different successional stages in southern China. Chinese Journal of Plant Ecology 35:946-954. DOI. 10.3724/SP.J.1258.2011.00946.

Hanson P.J., Edwards N.T., Garten C.T., Andrews J.A., 2000. Separating root and soil microbial contributions to soil respiration: A review of methods and observations. Biogeochemistry 48:115-146. DOI: 10.1023/a:1006244819642.

Harmon M., Bible K., Ryan M., Shaw D., Chen H., Klopatek J., Li X., 2004. Production, respiration, and overall carbon balance in an old-growth Pseudotsuga-Tsuga forest ecosystem. Ecosystems 7:498-512. DOI: $10.1007 / \mathrm{s} 10021-004-0140-9$.

IPCC, 2007 Climate Change 2007: Synthesis Report. Contribution of Working Groups I, II and III to the Fourth Assessment Report of the Intergovernmental Panel on Climate Change.

Kaspar T., Bland W.L., 1992. Soil temperature and root growth. Soil Science 154:290-299.

Kuzyakov Y., Gavrichkova O., 2010. Time lag between photosynthesis and carbon dioxide efflux from soil: a review of mechanisms and controls. Global Change Biology 16:3386-3406. DOI: 10.1111/j.1365- 
2486.2010.02179.x.

Law B.E., Falge E., Gu L., Baldocchi D.D., Bakwin P., Berbigier P., Davis K., Dolman A.J., Falk M., Fuentes J.D., Goldstein A., Granier A., Grelle A., Hollinger D., Janssens I.A., Jarvis P., Jensen N.O., Katul G., Mahli Y., Matteucci G., Meyers T., Monson R., Munger W., Oechel W., Olson R., Pilegaard K., Paw U K.T., Thorgeirsson H., Valentini R., Verma S., Vesala T., Wilson K., Wofsy S., 2002. Environmental controls over carbon dioxide and water vapor exchange of terrestrial vegetation. Agricultural and Forest Meteorology 113:97-120. DOI: 10.1016/S0168-1923(02)00104-1.

Law B.E., Ryan M.G., Anthoni P.M., 1999. Seasonal and annual respiration of a ponderosa pine ecosystem. Global Change Biology 5:169-182. DOI: 10.1046/j.13652486.1999.00214.x.

Lee K.-H., Jose S., 2003. Soil respiration, fine root production, and microbial biomass in cottonwood and loblolly pine plantations along a nitrogen fertilization gradient. Forest Ecology and Management 185:263-273. DOI: 10.1016/S0378-1127(03)00164-6.

Lee M.S., Nakane K., Nakatsubo T., Koizumi H., 2003. Seasonal changes in the contribution of root respiration to total soil respiration in a cool-temperate deciduous forest. Plant and Soil 255:311-318. DOI: 10.1023/A:1026192607512.

Lee N.-y., Koo J.-W., Noh N., Kim J., Son Y., 2010. Autotrophic and heterotrophic respiration in needle fir and Quercus-dominated stands in a cool-temperate forest, central Korea. Journal of Plant Research 123:485-495. DOI: $10.1007 / \mathrm{s} 10265-010-0316-7$.

Li H.J., Yan J.X., Yue X.F., Wang M.B., 2008. Significance of soil temperature and moisture for soil respiration in a Chinese mountain area. Agricultural and Forest Meteorology 148:490-503. DOI: 10.1016/j.agrformet.2007.10.009.

Li X., Fu H., Guo D., Li X., Wan C., 2010. Partitioning soil respiration and assessing the carbon balance in a Setaria italica (L.) Beauv. Cropland on the Loess Plateau, Northern China. Soil Biology and Biochemistry 42:337-346. DOI: 10.1016/j.soilbio.2009.11.013.

Li Y., Jian H., Yuan F., 2010. Soil respiration and its regulating factors in the Phyllostachys edulis forest of west Tianmu Mountain. Acta Ecologica Sinica 30:45904597 (in Chinese with English abstract).

Li Y.Q., Xu M., Zou X.M., 2006. Heterotrophic soil respiration in relation to environmental factors and microbial biomass in two wet tropical forests. Plant and Soil 281:193-201. DOI: 10.1007/s11104-005-4249-1.

Li Z., Wang X., Zhang R., Zhang J., Tian C., 2011. Contrasting diurnal variations in soil organic carbon decomposition and root respiration due to a hysteresis effect with soil temperature in a Gossypium s. (cotton) plantation. Plant and Soil 343:347-355. DOI: 10.1007/ s11104-011-0722-1.

Liu J., Jiang P.K., Wang H.L., Zhou G.M., Wu J.S., Yang F., Qian X.B., 2011. Seasonal soil $\mathrm{CO}_{2}$ efflux dynamics after land use change from a natural forest to Moso bamboo plantations in subtropical China. Forest Ecology and Management 262:1131-1137. DOI: 10.1016/j. foreco.2011.06.015.

Liu M., Qi L., Yuan L., 2012. Characteristics of climate change from 1960 to 2009 Xianning, Hubei Province. Journal of Meteorology and Environment 28:71-76 (in Chinese with English abstract).

Luan J.W., Liu S.R., Wang J.X., Zhu X.L., Shi Z.M., 2011. Rhizospheric and heterotrophic respiration of a warm-temperate oak chronosequence in China. Soil Biology and Biochemistry 43:503-512. DOI: 10.1016/j. soilbio.2010.11.010.

Luo Y., Zhou X., 2006. Soil respiration and the environment, Academic press, San Diego, California. pp 18-20.

Ma Y., Piao S., Sun Z., Lin X., Wang T., Yue C., Yang Y., 2014. Stand ages regulate the response of soil respiration to temperature in a Larix principis-rupprechtii plantation. Agricultural and Forest Meteorology 184:179-187. DOI: 10.1016/j.agrformet.2013.10.008.

Malhi Y., Baldocchi D.D., Jarvis P.G., 1999. The carbon balance of tropical, temperate and boreal forests. Plant, Cell \& Environment 22:715-740. DOI: 10.1046/j.13653040.1999.00453.x.

Manzoni S., Taylor P., Richter A., Porporato A., Ågren G.I., 2012. Environmental and stoichiometric controls on microbial carbon-use efficiency in soils. New Phytologist 196:79-91. DOI: 10.1111/j.14698137.2012.04225.x.

McClaugherty C.A., Aber J.D., Melillo J.M., 1982. The role of fine roots in the organic matter and nitrogen budgets of two forested ecosystems. Ecology 63:14811490.

Perucci P., Dumontet S., Bufo S.A., Mazzatura A., Casucci C., 2000. Effects of organic amendment and herbicide treatment on soil microbial biomass. Biology and Fertility of Soils 32:17-23. DOI: 10.1007/s003740000207.

Pregitzer K.S., King J.S., Burton A.J., Brown S.E., 2000. Responses of tree fine roots to temperature. New Phytologist 147:105-115. DOI: 10.1046/j.14698137.2000.00689.x.

Pregitzer K.S., Laskowski M.J., Burton A.J., Lessard V.C., Zak D.R., 1998. Variation in sugar maple root respiration with root diameter and soil depth. Tree Physiology 18:665-670. DOI: 10.1093/treephys/18.10.665.

R Core Team (2014) R: A language and environment for statistical computing. R Foundation for Statistical Computing, Vienna, Austria. Web: http:/www.R-project. org/. Accessed: 06.032015.

Raich J.W., Nadelhoffer K.J., 1989. Belowground carbon allocation in forest ecosystems: global trends. Ecology 70:1346-1354. DOI: 10.2307/1938194.

Raich J.W., Schlesinger W.H., 1992. The global carbon dioxide flux in soil respiration and its relationship to vegetation and climate. Tellus B 44:81-99. DOI: 10.1034/ j.1600-0889.1992.t01-1-00001.x.

Rey A., Pegoraro E., Tedeschi V., De Parri I., Jarvis P.G., Valentini R., 2002. Annual variation in soil respiration and its components in a coppice oak forest in Cen- 
tral Italy. Global Change Biology 8:851-866. DOI: 10.1046/j.1365-2486.2002.00521.x.

Ryan M.G., Hubbard R.M., Pongracic S., Raison R.J., McMurtrie R.E., 1996. Foliage, fine-root, woody-tissue and stand respiration in Pinus radiata in relation to nitrogen status. Tree Physiology 16:333-343. DOI: 10.1093/treephys/16.3.333.

Ryan M.G., Lavigne M.B., Gower S.T., 1997. Annual carbon cost of autotrophic respiration in boreal forest ecosystems in relation to species and climate. Journal of Geophysical Research: Atmospheres 102:28871-28883. DOI: 10.1029/97jd01236.

Silver W.L., Miya R.K., 2001. Global patterns in root decomposition: comparisons of climate and litter quality effects. Oecologia 129:407-419. DOI: 10.1007/ s004420100740.

Song X., Yuan H., Kimberley M.O., Jiang H., Zhou G., Wang H., 2013. Soil $\mathrm{CO}_{2}$ flux dynamics in the two main plantation forest types in subtropical China. Science of the Total Environment 444:363-368. DOI: 10.1016/j. scitotenv.2012.12.006.

Song X.Z., Peng C.H., Zhao Z.Y., Zhang Z.T., Guo B.H., Wang W.F., Jiang H., Zhu Q.A., 2014. Quantification of soil respiration in forest ecosystems across China. Atmospheric Environment 94:546-551. DOI: 10.1016/j. atmosenv.2014.05.071.

State Forestry Administration, 2014 Report for Chinese forest resource - The 8th national forest inventory, China Forestry Publishing House, Beijing China, pp 94.

Subke J.-A., Bahn M., 2010. On the 'temperature sensitivity' of soil respiration: Can we use the immeasurable to predict the unknown? Soil Biology and Biochemistry 42:1653-1656. DOI: 10.1016/j.soilbio.2010.05.026.

Subke J.-A., Inglima I., Francesca Cotrufo M., 2006. Trends and methodological impacts in soil $\mathrm{CO}_{2}$ efflux partitioning: A metaanalytical review. Global Change Biology 12:921-943. DOI: 10.1111/j.13652486.2006.01117.x.

Tan Z., Zhang Y., Yu G., Sha L., Tang J., Deng X., Song Q., 2010. Carbon balance of a primary tropical seasonal rain forest. Journal of Geophysical Research: Atmospheres 115:D00H26. DOI: 10.1029/2009jd012913.

Tang J.W., Baldocchi D.D., Xu L.K., 2005. Tree photosynthesis modulates soil respiration on a diurnal time scale. Global Change Biology 11:1298-1304. DOI: 10.1111/j.1365-2486.2005.00978.x.

Tang X., Fan S., Qi L., Guan F., Cai C., Du M., 2015. Soil respiration and carbon balance in a Moso bamboo (Phyllostachys heterocycla (Carr.) Mitford cv. Pubescens) forest in subtropical China. iForest - Biogeosciences and Forestry 8:606-614. DOI: 10.3832ifor1360007.

Tang X., Fan S., Qi L., Liu G., Guan F., Du M., Shen C., 2012. Effect of different managements on carbon storage and carbon allocation in Moso Bamboo Forest (Phyllostachys pubescen). Acta Agriculturae Universitatis Jiangxiensis 34:736-742 (in Chinese with English abstract).
Tian D., Wang G., Peng Y., Yan W., Fang X., Zhu F., Chen X., 2011. Contribution of autotrophic and heterotrophic respiration to soil $\mathrm{CO}_{2}$ efflux in Chinese fir plantations. Australian Journal of Botany 59:26-31. DOI: 10.1071/ bt10191.

Tu L.H., Hu T.X., Zhang J., Li X.W., Hu H.L., Liu L., Xiao Y.L., 2013. Nitrogen addition stimulates different components of soil respiration in a subtropical bamboo ecosystem. Soil Biology and Biochemistry 58:255-264. DOI: $10.1016 /$ j.soilbio.2012.12.005.

Wang C., Gower S.T., Wang Y., Zhao H., Yan P., Bond-Lamberty B.P., 2001. The influence of fire on carbon distribution and net primary production of boreal Larix gmelinii forests in north-eastern China. Global Change Biology 7:719-730. DOI: 10.1046/j.13541013.2001.00441.x.

Wang C., Yang J., 2007. Rhizospheric and heterotrophic components of soil respiration in six Chinese temperate forests. Global Change Biology 13:123-131. DOI: 10.1111/j.1365-2486.2006.01291.x.

Wang C., Yang Z.J., Chen G.S., Fan Y.X., Liu Q., Tian H., 2011. Characteristics of soil respiration in Phyllostachys edulis forest in Wanmulin Natural Reserve and related affecting factors. Chinese Journal of Applied Ecology 22:1212-1218 (In Chinese).

Wang G.P., Innes J.L., Dai S.Y., He G.H., 2008. Achieving sustainable rural development in Southern China: the contribution of bamboo forestry. International Journal of Sustainable Development and World Ecology 15:484-495. DOI: 10.3843/Susdev.15.5:9.

Wang W., Chen W., Wang S., 2010. Forest soil respiration and its heterotrophic and autotrophic components: Global patterns and responses to temperature and precipitation. Soil Biology and Biochemistry 42:12361244. DOI: 10.1016/j.soilbio.2010.04.013.

Wang X.L., Zhao J., Wu J.P., Chen H., Lin Y.B., Zhou L.X., Fu S.L., 2011. Impacts of understory species removal and/or addition on soil respiration in a mixed forest plantation with native species in southern China. Forest Ecology and Management 261:1053-1060. DOI: 10.1016/j.foreco.2010.12.027.

Wu C., Zhang Y., Xu X., Sha L., You G., Liu Y., Xie Y., 2014. Influence of interactions between litter decomposition and rhizosphere activity on soil respiration and on the temperature sensitivity in a subtropical montane forest in SW China. Plant and Soil 381:215-224. DOI: 10.1007/s11104-014-2106-9.

Wu J., Liu Z., Chen D., Huang G., Zhou L., Fu S., 2011. Understory plants can make substantial contributions to soil respiration: Evidence from two subtropical plantations. Soil Biology and Biochemistry 43:2355-2357. DOI: 10.1016/j.soilbio.2011.07.011.

Wu J.J., Yang Z.J., Liu X.F., Xiong D.C., Lin W.S., Chen C.Q., Wang X.H., 2014. Analysis of soil respiration and components in Castanopsis carlesii and Cunninghamia lanceolata plantations. Chinese Journal of Plant Ecology 38:45-53. DOI. 10.3724/SP.J.1258.2014.00005.

Xiao F., Fan S., Wang S., Guan F., Yu X., Shen Z., 2010. 
Estimation of carbon balance in Moso bamboo forest and Chinese fir plantation ecosystem. Scientia Silvae Sinicae 46:59-65 (In Chinese with English abstract).

Yan J., Wang Y., Zhou G., Zhang D., 2006. Estimates of soil respiration and net primary production of three forests at different succession stages in South China. Global Change Biology 12:810-821. DOI: 10.1111/j.13652486.2006.01141.X.

Yan M., Guo N., Ren H., Zhang X., Zhou G., 2015. Autotrophic and heterotrophic respiration of a poplar plantation chronosequence in northwest China. Forest Ecology and Management 337:119-125. DOI: 10.1016/j. foreco.2014.11.009.

Yang Y.S., Chen G.S., Guo J.F., Xie J.S., Wang X.G., 2007. Soil respiration and carbon balance in a subtropical native forest and two managed plantations. Plant Ecology 193:71-84. DOI: 10.1007/s11258-006-9249-6.

Yuste J.C., Janssens I.A., Carrara A., Meiresonne L., Ceulemans R., 2003. Interactive effects of temperature and precipitation on soil respiration in a temperate maritime pine forest. Tree Physiology 23:1263-1270. DOI: 10.1093/treephys/23.18.1263.

Zhang H.X., Zhuang S.Y., Sun B., Ji H.B., Li C.M., Zhou S., 2014. Estimation of biomass and carbon storage of moso bamboo (Phyllostachys pubescens Mazel ex
Houz.) in southern China using a diameter-age bivariate distribution model. Forestry 87:674-682. DOI: 10.1093/ forestry/cpu028.

Zhang J., Li Y., Chang S.X., Jiang P., Zhou G., Liu J., Wu J., Shen Z., 2013. Understory vegetation management affected greenhouse gas emissions and labile organic carbon pools in an intensively managed Chinese chestnut plantation. Plant and Soil 2013:1-13. DOI. 10.1007/ s11104-013-1996-2.

Zhang W.R., Yang G.Y., Tu X.N., Zhang P., 1999. Determinatlon of organic matter in forest soil and calculation carbon-nitrogen ratio. In: Zhang W.R., Yang G.Y., Tu X.N., Zhang P. (eds.), Standards of forest soil measurement. China Standard Press, Beijing, China, pp. 105108 (In Chinese).

Zhou G., Jiang P., 2004. Density, storage and spatial distributbion of carbon in Phyllostachy pubescens forest. Scientia Silvae Sinicae 40:20-24 (In Chinese with English abstract).

Zhou G., Jiang P., Xu Q. 2010. Carbon sequestration and transform in bamboo ecosystem, Science Press, Beijing, China, pp 105-137 (In Chinese).

Zhu W.Z., 2013. Advances in the carbon use efficiency of forest. Chinese Journal of Plant Ecology 37:1043-1058. DOI: 10.3724/SP.J.1258.2013.00108. 